ISSN 0258-7122

Bangladesh J. Agril. Res. 34(3) : 403-410, September 2009

\title{
EFFECT OF DIFFERENT HOST PLANTS ON GROWTH AND DEVELOPMENT OF EPILACHNA BEETLE
}

\author{
M.S. HOSSAIN, A.B. KHAN, M.A. HAQUE \\ M.A.MANNAN AND C.K. DASH
}

\begin{abstract}
An experiment was conducted to study the effect of four different host plants viz., teasel gourd, bitter gourd, sponge gourd, and yard long bean on the growth and development of Epilachna dodecastigma Wied under laboratory condition. The number of eggs laid by female beetle was significantly highest feeding on teasel gourd leaves and lowest on yardlong bean leaves. Egg hatching was faster on yardlong bean and delayed on bitter gourd. The host plant, such as sponge gourd produced the large sized larvae, while large pupa and adult were developed by feeding teasel leaves. The smallest larvae, pupae, and adults were found on the consumption of yardlong bean leaves. Highest larval duration was found on sponge gourd followed by bitter gourd and yardlong bean. Both larval and adult food consumption was highest on teasel gourd and lowest on yardlong bean. Considering the biological characteristics and leaf consumption, the plant teasel gourd appeared to be the best host plant for E. dodecastigma.
\end{abstract}

Key Words: Host plant, growth and development, Epilachna dodecastigma, leaf consumption.

\section{Introduction}

Epilachna beetle, Epilachna dodecastigma Wied is a very important insect pest of vegetables. It is widely distributed in South and East Asia, Australia, America and the East Indies. Two species of epilachna beetle viz., Epilachna dodecastigma (Wied.) and Epilachna vigintioctopunctata Fab are serious pests of vegetables in Bangladesh (Khan et al., 2000). Epilachna dodecastigma is fairly common and causes damage to the solanaceous and cucurbitaceous crops (Khan et al., 2000). The peak period of infestation varies with regions. Generally the peak is found in July and August. Both adult beetles and grubs feed on the epidermal tissues of the leaves by scrapping, resulting drying up and falling the leaves. Sometimes it is called a leaf scrapping coccinellid beetle (Imura and Ninomiya, 1978). The growth and development of the plants are greatly hampered and the yield is markedly reduced by its attack (Alam, 1969). The nature of damage by the larvae is somewhat distinct from that of the adults. The grubs confine their attack to the lower surface of the leaves and adults usually feed on the upper surface of the leaves (Prodhan et al., 1990). The third and fourth instar grubs are more destructive and voracious. Rajgopal and Trivedi

Department of Entomology, Bangladesh Agricultural University, Mymensingh, Bangladesh. 
(1989) reported that epilachna beetle may damage upto $80 \%$ of plants depending on place and season for variations of prevailing environmental conditions. Epilachna beetle feeds actively in the morning and evening hours and feeding declines rapidly in the middle of the day and after midnight (Tilavov, 1981). The daily fluctuation in the rate of feeding depends mainly on the temperature which determined the level of metabolism (Tilavov, 1981).

For the selection and execution of any pest management, the basic requirement is to study the biology of the pest on its growth and development on longevity, fecundity, and mortality in relation to the host plants. Research works in this aspect are scanty in Bangladesh. The present study was undertaken to investigate the suitable hosts for E. dodecastigma.

\section{Materials and Method}

The experiment was conducted to determine the effect of leaves of four different plants as host on the growth and development of Epilachna beetle in the laboratory of Department of Entomology, Bangladesh Agricultural University (BAU), Mymensingh during July to October 2007. The prevailing room temperature was $30 \pm 2^{\circ} \mathrm{C}$ with $80 \pm 5 \%$ R.H. Teasel gourd (Momordica dioica Roxb.), bitter gourd (Momordica charantia L.), sponge gourd (Luffa cylindrica) and yardlong bean (Vigna sesquipedalis) leaves were used as food. For supply of test insect, the adult beetles were collected from the host plants for maintaining the stock culture in the laboratory. Field collected adult beetles were sexed and confined in pairs in the Petri dishes ( $7.5 \mathrm{~mm}$ diameter) for mating and ovipositon. Fresh and healthy leaves of four host plants were separately supplied every day for them. After oviposition, adult beetles were transferred to different Petri dishes and the deposited eggs were kept undisturbed for hatching. Immediately after hatching, ten larvae were transferred to each Petri dish $(7.5 \mathrm{~mm})$ for rearing upto adult emergence. The newly emerged adults were again sexed and confined in pairs in Petri dishes for mating and laying eggs. This culture was maintained in order to avoid the effect of previous food plants on the biology of the test insect.

From laboratory stock, the grubs immediately after hatching were transferred to previously marked Petridishes (9.0 cm diameter) with the help of a soft camel hair brush. Moistened blotting papers were placed to cover the bottom of each petridish. One grub was reared in each Petridish. Fresh leaves of four different host plants were provided to the larvae at 24 hours interval in the morning and uneaten leaves along with faeces were removed. The larvae were observed daily until pupation to record the number of larval instars and their duration. Ten replicates were used for each host plant. The dishes were placed randomly on the 
table in the laboratory. Care was taken to avoid injury to the skin of the grubs and good hygienic condition was maintained in the rearing dishes. The pupae were kept undisturbed in the respective Petridishes until the adult emergence and recorded pupal duration. Initiation and completion of each grub stage were keenly observed. The length and breadth of grub at each instar and pupae were measured from 20 specimens using a micrometer under a stereomicroscope and was recorded.

To estimate the leaf consumption, newly hatched larvae and newly emerged adults were individually placed from laboratory culture in each petridish containing leaves of four different plants as food. Ten petridishes were maintained for each host plant. Fresh leaves were supplied daily. Wet cotton was used to maintain humidity inside the Petridishes. Leaf consumption of Epilachna dodecastigma Wied was estimated by exposing first, second, third, and final instar larvae as well as adult beetles to different host plants. The leaf area consumed by each larval - instar and adult beetles were measured by using a square millimeter graph paper. In case of larvae, this measurement was continued upto pupation and for adult upto death.

Data obtained were analyzed using analysis of variance in Completely Randomized Design (CRD) and mean values were separated by Duncan's New Multiple Range Test (DMRT).

\section{Results and Discussion}

\section{Oviposition}

The female beetle of $E$. dodecastigma laid eggs in cluster on the dorsal surface of the leaf. They were closely held in a cluster. It was found that $E$. dodecastigma laid eggs on all tested host plants and the rate of oviposition was high during the first few days of exposure for feeding (Fig. 1). Number of eggs laid per female and oviposition period differed significantly on four diffferent host plants (Table 1 ). The highest number of eggs were laid on teasel gourd leaves (268.00 \pm 33.99$)$ and next on sponge gourd, bitter gourd, and yard long bean. Significantly longest oviposition period was observed in yard long bean (8.70 1.15 days) and shortest in teasel gourd ( $5.55 \pm 0.41$ days). From the results, it was found that teasel gourd leaf feeding resulted shortest oviposition period with highest number of eggs laid per female, while yard long bean as host resulted longest oviposition period with lowest number of eggs. These variations might be due to the difference in nutritive values of the host plants. The present findings were supported by Jones et al. (1981) and Rahman (2002). 
Table 1. Oviposition period and fecundity of E. dodecastigma fed on four different host plants

\begin{tabular}{l|l|l}
\hline \multicolumn{1}{c|}{ Host plants } & \multicolumn{1}{c|}{$\begin{array}{c}\text { Oviposition period (days) } \\
(\text { Mean } \pm \text { SE) }\end{array}$} & \multicolumn{1}{c}{$\begin{array}{c}\text { Eggs per female (no.) } \\
\text { (Mean } \pm \text { SE) }\end{array}$} \\
\hline Teasel gourd & $5.55 \pm 0.41 \mathrm{~d}$ & $268.00 \pm 33.99 \mathrm{a}$ \\
Bitter gourd & $6.62 \pm 0.55 \mathrm{c}$ & $198.00 \pm 4.71 \mathrm{c}$ \\
Sponge gourd & $7.80 \pm 0.38 \mathrm{~b}$ & $250.00 \pm 8.16 \mathrm{~b}$ \\
Yardlong bean & $8.70 \pm 1.15 \mathrm{a}$ & $164.00 \pm 5.08 \mathrm{~d}$ \\
\hline
\end{tabular}

Figures in column with different letters are significantly different.

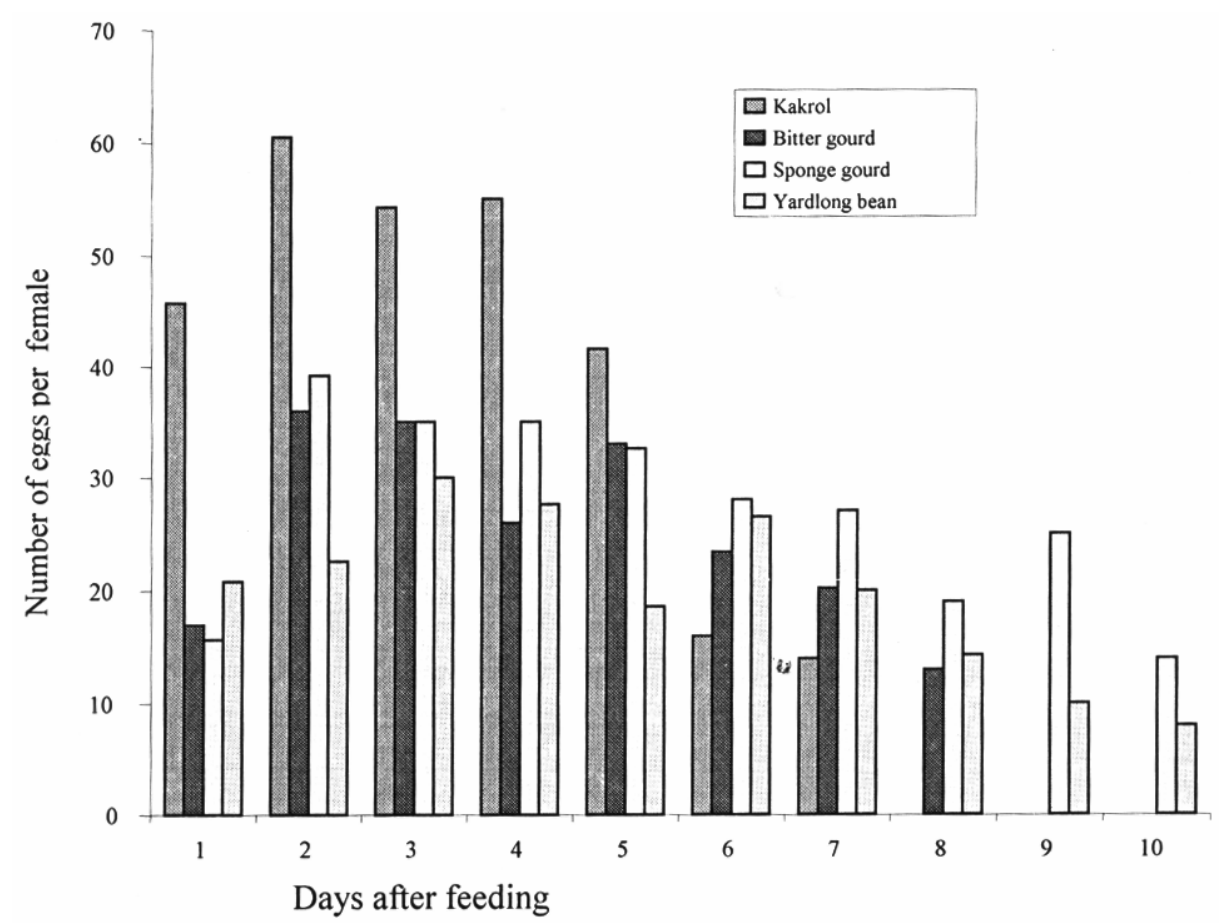

Figure 1. Daily egg laying pattern of E. dodecastigma on different host plants.

\section{Egg}

Eggs of Epilachna dodecastigma were yellow in colour and spindle shaped tapering at the micropylar region. The length and breadth of egg were highest in teasel gourd $(1.09 \pm 0.04$ and $0.38 \pm 0.05 \mathrm{~mm})$, which were statistically identical to those of sponge gourd and bitter gourd and the lowest was in yardlong bean $(0.60 \pm 0.12$ and $0.35 \pm 0.02 \mathrm{~mm})$ (Table 2). Statistically longest incubation period was recorded in bitter gourd (4.19 \pm 0.23 days) and shortest in yard long bean (3.15 \pm 0.32 days). Host plants had no significant effect on egg hatching rate. 
Austin (1925) observed 3 to 5 days of incubation period on solanaceous plants and 5 to 7 days on cucurbitaceous plants.

Table: 2. Egg size, incubation period and percent egg hatching of E. dodecastigma fed on the leaves of four different host plants.

\begin{tabular}{|c|c|c|c|c|}
\hline Host plant & \multicolumn{2}{|c|}{ Egg } & \multirow{2}{*}{$\begin{array}{c}\text { Incubation } \\
\text { period } \\
\text { (days) }\end{array}$} & \multirow{2}{*}{$\begin{array}{c}\text { Egg hatched (\%) } \\
\text { (Mean } \pm \text { SE) }\end{array}$} \\
\hline & $\begin{array}{c}\text { Length (mm) } \\
(\text { Mean } \pm \text { SE) }\end{array}$ & $\begin{array}{c}\text { Breadth }(\mathrm{mm}) \\
(\text { Mean } \pm \text { SE) }\end{array}$ & & \\
\hline Teasel gourd & $1.09 \pm 0.04 \mathrm{a}$ & $0.38 \pm 0.05 \mathrm{a}$ & $3.82 \pm 0.10 \mathrm{~b}$ & $85.73 \pm 6.24$ \\
\hline Bittergourd & $1.07 \pm 0.03 \mathrm{a}$ & $0.36 \pm 0.02 \mathrm{a}$ & $4.19 \pm 0.23 \mathrm{a}$ & $80.33 \pm 2.36$ \\
\hline Sponge gourd & $1.08 \pm 0.05 \mathrm{a}$ & $0.37 \pm 0.02 \mathrm{a}$ & $4.05 \pm 0.11 b$ & $83.08 \pm 4.92$ \\
\hline Yard long bean & $0.60 \pm 0.12 b$ & $035 \pm 0.02 \mathrm{~b}$ & $3.15 \pm 0.32$ c & $80.63 \pm 8.16$ \\
\hline
\end{tabular}

Figures in column with different letters are significantly different.

\section{Larva}

E. dodecastigma had four instars. Immediately after hatching neonate grubs were light yellow in colour with branching body hairs. The length and breadth of final instar grubs were highest feeding on leaves of sponge gourd $(7.90 \pm 0.27 \mathrm{~mm}$, $6.95 \pm 0.43 \mathrm{~mm})$, which were statistically identical to teasel gourd $(7.82 \pm 0.38 \mathrm{~mm}$, $6.93 \pm 0.09 \mathrm{~mm})$ and bitter gourd $(7.71 \pm 0.09 \mathrm{~mm}, 6.83 \pm 0.38 \mathrm{~mm})$. The lowest length and breadth of grub were measured when fed on yard long bean $(5.32 \pm 0.22 \mathrm{~mm}, 3.20 \pm 0.13 \mathrm{~mm})$ (Table 3$)$. Total duration of grub was the highest on sponge gourd (11.38 \pm 0.53 days), which was followed by bitter gourd (11.05 \pm 0.82 days). Teasel gourd showed significantly lowest grub duration (9.58 \pm 0.33 days). Pradhan (1969) showed the total duration of grub ranging from 12 to 25 days on different host plants. The findings of the above author indicated that there was considerable variation in larval duration and such variation might be due to the suitability and nutritional quality of host plants as food.

Table 3. Body size and total duration of grub and pupa of E. dodecastigma fed on four different host plant leaves.

\begin{tabular}{|c|c|c|c|c|c|c|}
\hline \multirow[t]{2}{*}{ Host plant } & \multicolumn{2}{|c|}{ Final instar grub } & \multirow{2}{*}{$\begin{array}{c}\text { Total grub } \\
\text { duration (days) } \\
\text { (Mean } \pm \text { SE) }\end{array}$} & \multicolumn{2}{|c|}{ Pupa } & \multirow{2}{*}{$\begin{array}{c}\text { Pupal period } \\
\text { (days) } \\
\text { (Mean } \pm \text { SE) }\end{array}$} \\
\hline & $\begin{array}{l}\begin{array}{c}\text { Length } \\
(\mathrm{mm})\end{array} \\
(\mathrm{Mean} \pm \\
\mathrm{SE})\end{array}$ & \begin{tabular}{|c} 
Breadth \\
(mm) \\
(Mean \pm \\
SE)
\end{tabular} & & $\begin{array}{c}\text { Length } \\
(\mathrm{mm})(\text { Mean } \\
\pm \mathrm{SE})\end{array}$ & $\begin{array}{c}\text { Breadth } \\
(\mathrm{mm}) \\
(\text { Mean } \pm \mathrm{SE})\end{array}$ & \\
\hline Teasel gourd & $7.82 \pm 0.38 \mathrm{a}$ & $6.93 \pm 0.09 \mathrm{a}$ & $9.58 \pm 0.33 c$ & $7.52 \pm 0.24 \mathrm{a}$ & $6.24 \pm 0.47$ a & $5.32 \pm 0.47 \mathrm{a}$ \\
\hline Bitter gourd & $7.71 \pm 0.09 \mathrm{a}$ & $6.83 \pm 0.38$ a & $11.0 \mathrm{~S} \pm 0.82 \mathrm{ab}$ & $7.25 \pm 0.23 \mathrm{a}$ & $6.12 \pm 0.82 \mathrm{a}$ & $5.50 \pm 0.24 \mathrm{a}$ \\
\hline Sponge gourd & $7.90 \pm 0.27 \mathrm{a}$ & $6.95 \pm 0.43$ a & $11.38 \pm 0.53 \mathrm{a}$ & $7.43 \pm 0.47$ a & $6.13 \pm 0.48 \mathrm{a}$ & $4.20 \pm 0.23 \mathrm{~b}$ \\
\hline Yardlong bean & $5.3 \pm 0.22 b$ & $3.20 \pm 0.13 b$ & $10.70 \pm 0.82 b$ & $5.15 \pm 0.47 \mathrm{~b}$ & $2.93 \pm 0.42 \mathrm{~b}$ & $4.15 \pm 0.94 \mathrm{~b}$ \\
\hline
\end{tabular}

Figures in colunm with different letters are significantly different. 


\section{Pupa}

The pupa of E. dodecastigma was exarate obteel type. The whole body was covered dorsally with small bristle. The length and breadth of pupae developed from teasel gourd were highest $(7.52 \pm 0.24 \mathrm{~mm}, 6.24 \pm 0.47 \mathrm{~mm})$, which was statistically similar to bitter gourd and sponge gourd. Significantly lowest measurement of the pupa was observed on yardlong bean (Table 3). Pupal period was highest on bitter gourd (5.50 \pm 0.24 days), which was statistically similar to teasel gourd. The lowest pupal period was found when consuming yard long bean leaf (4.15 \pm 0.94 days) and this was statistically identical with that of sponge gourd. The results of the present study were in partial agreement with the findings of Rahman (2002) and Shanmugapriyan and Kingsly (2003).

\section{Adult}

Just after emergnce, the colour of the beetle was bright yellow and distinct spots were not clearly visible on the elytra. After 14 to 20 minutes, the spots appeared and the general body colour gradually turned to almost dark brown. The adult beetls had six black round spots on each elytron. The length and breadth of adults were highest when fed on teasel gourd leaves $(6.83 \pm 0.38 \mathrm{~mm}, 5.43 \pm 0.19 \mathrm{~mm})$ followed by sponge gourd and bitter gourd leaves and lowest on yardlong bean (Table 4.) The highest longevity was found on yardlong bean (35.60 \pm 5.27 days), which was statistically identical to those fed on teasel gourd (33.63 \pm 4.92 days) and lowest was on bitter gourd and sponge gourd. Rahman (2002) showed the same results to study the feeding behaviour and fcod preferences of epilachna beetle on different host plants.

Table 4. Size and longevity of adult of E. dodecastigma fed on the leaves of four different host plants.

\begin{tabular}{l|l|l|l}
\hline \multirow{2}{*}{ Host plant } & \multicolumn{1}{c|}{$\begin{array}{c}\text { Adult longevity } \\
\text { (days) (Mean } \pm \text { SE) }\end{array}$} & \multicolumn{1}{c}{ Adult } \\
\cline { 3 - 4 } & & $\begin{array}{r}\text { Length }(\mathrm{mm}) \\
\text { (Mean } \pm \text { SE) }\end{array}$ & $\begin{array}{r}\text { Breadth }(\mathrm{mm}) \\
\text { (Mean } \pm \text { SE) }\end{array}$ \\
\hline Teasel gourd & $33.63 \pm 4.92 \mathrm{a}$ & $6.83 \pm 0.38 \mathrm{a}$ & $5.43 \pm 0.19 \mathrm{a}$ \\
Bitter gourd & $27.20 \pm 0.94 \mathrm{~b}$ & $6.34 \pm 0.53 \mathrm{~b}$ & $5.01 \pm 0.47 \mathrm{~b}$ \\
Spongegourd & $29.40 \pm 2.88 \mathrm{~b}$ & $6.77 \pm 0.58 \mathrm{~b}$ & $5.28 \pm 0.23 \mathrm{ab}$ \\
Yardlong bean & $35.60 \pm 5.27 \mathrm{a}$ & $4.25 \pm 0.48 \mathrm{c}$ & $3.73 \pm 0.47 \mathrm{c}$ \\
\hline
\end{tabular}

Figures in column with different letters are significantly different

\section{Leaf consumption}

Leaf consumption of grub gradually increased with the increase of larval age. The total leaf consumption by the grub and adult was found statistically highest when fed on teasel gourd and lowest on yardlong bean (Table 5). Leaf 
consumption by the adult on sponge gourd and bitter gourd was statistically similar. Results revealed that for both grubs and adults of $E$. dodecastigma, the teasel gourd leaf might be the most suitable host for consumption. Leaf consumption rate of grub feeding on different hosts might be influenced by many factors. Different chemical stimuli and physiological factors present in host plants might influence the food consumption rate of epilachna beetle (Jones et al.,1981) Richards and Filewood (1990) stated that food preference of $E$. vigintioctopunctata was influenced by odour, taste, and age of host plant and also by thickness of leaves, proportion of crude fibres, parenchymatous tissue and water content.

Table 5. Leaf consumption $\left(\mathrm{mm}^{2}\right)$ of four different host plants per grub and adult of E. dodecastigma.

\begin{tabular}{l|ll}
\hline \multirow{2}{*}{ Host plant } & \multicolumn{2}{c}{ Total leaf consumption $\left(\mathrm{mm}^{2}\right)$} \\
\cline { 2 - 3 } & \multicolumn{1}{c}{ Larva (Mean \pm SE) } & Adult (Mean \pm SE) \\
\hline Teasel gourd & $2540 \pm 535.41 \mathrm{a}$ & $26490 \pm 188.56 \mathrm{a}$ \\
Bitter gourd & $2356 \pm 141.42 \mathrm{a}$ & $12820 \pm 942.81 \mathrm{~b}$ \\
Sponge gourd & $1635.56 \pm 374.42 \mathrm{~b}$ & $1530 \pm 49.22 \mathrm{~b}$ \\
Yardlong bean & $1082.25 \pm 95.78 \mathrm{c}$ & $12719 \pm 1616.00 \mathrm{c}$ \\
\hline
\end{tabular}

Figures in column with different letters are significantly different

\section{References}

Alam, M.Z. 1969. Insect pests of vegetables and their control in East Pakistan. Agril. Inf. Serv., Department of Agriculture, R.K. Mission Road, Dhaka, 149 p.

Austin, G.O. 1925. Some beetle pests of cucurbits in Ceylon Rev. Appi. Entomol. Series A, 13(7): 358.

Imura, 0. and S. Ninomiya. 1978. Quantitative measurement of leaf area consumption by Epilachna vigintioctopunctata (Fabricius) (Coleoptera: Coccinellidae) using image processing. Appl. Ent. Zool. 33(4): 491-495.

Jones, C.G., M.P. Hoggard, and M.S. Blum. 1981. Pattern and process in insect feeding behaviour: a quantitative analysis of the Mexican bean beetle, Epilachna varivestis. Ent. Expt. AppI. 30(3): 254-264.

Khan, M.H., B.N., Islam, A.K.M.M. Rahman and M.L. Rahman. 2000. Life table and the rate of food consumption of epilaclina beetle, Epilachna d\%odecastigma (Wied.) on different host plant species in laboratory condition. Bangladesh J. Ent. 10(1-2): 63-70.

Prodhan, S., M.G. Jotwani and S. Prakash. 1990. Comparative toxicity of insecticides to the grub and adult of Epilachna vigintioctopunctata Fab. (Coleoptera: Coccinellidae). Indian J. Ent. 24(4): 223.

Rahman, M.M. 2002. Studies on the biology, feeding behaviour and food preferences of Epilachna dodecastigina (Wied.) on different host plants. M.S. thesis. Department of Entomology. Bangladesh Agricultural University, Mymensingh. 
Rajagopal, D. and T.P. Trivedi. 1989. Status biology and management of epilachna beetle, Epilachna vigintioctopunctata Fab. (Coleoptera: Coccinellidae) on potato in India. Trop. Pest Manag. 35(4): 410-413.

Richard, A.M. and L.W. Filewood. 1990. Feeding behaviour and food preferences of the pest species comprising the Epilachna vigintioctopunctata Fab. Complex (Coleoptera: Coccinellidae). J. Appi. Ent. Univ. New South Wales, Kensington, Australia 110(5): 501-515.

Shanmugapriyan, R. and S. Kingsly. 2003. The biology of the beetle, Epilachna vigintioctopunctata Fab. On cucurbits. Journal of Ecobiology 15(6): 445-449.

Tilavov, T.T. 1981. The daily and seasonal feeding rhythm of the adult of the cucumber beetle, Epilachna chrysomelina Fab. Uzbekskei Biologiceskii Zhurnal 8(5): 40-61. 